\title{
Effect of Different Parameters on the Binding of Two Anti-Inflammatory Drugs to Human Serum Albumin
}

\author{
CRISTINA ZONA, * GIANNA ROSCETTI, ${ }^{*}$ FRANCESCA VENTURELLI* \\ AND L. GIORGIO RODA ${ }^{+1}$ \\ *Dıpartimento di Medıcina Sperımentale e Sctenze Bıochimiche, "Tor Vergata" Unıverstty, Rome, Italy \\ †Laboratorio di Farmacologia, University of Ancona, Ancona, Italy
}

Received 3 January 1985

\begin{abstract}
ZONA, C , G ROSCETTI, F VENTURELLI AND L G RODA Effect of different parameters on the binding of two anti-inflammatory drugs to human serum albumin PHARMACOL BIOCHEM BEHAV 24(4) 1031-1037, 1986 -The binding to human serum albumın of two ant1-inflammatory drugs, indomethacin and indoprofen, has been studied by chromatographic and spectroscopic techniques The resulis shown indicate that the binding of both drugs-but more notably of indoprofen-is very sensitive to vanations of the environmental conditions The binding is also dependent upon limited modifications in the tertiary structure of the protein The evidences shown tend to indicate that these two phenomena are related, and that the binding is permitted under conditions of a relatively open structure of the protein molecule
\end{abstract}

Human serum albumın Indomethacın Indoprofen Antı-ınflammatory drug bindıng

SERUM albumıns are multiple-function proteins present at very high (up to $55 \mathrm{mg} / \mathrm{ml}$ ) concentration in the plasma of vertebrates Because of their abundance in plasma-and hence ease of purification-and because these proteins act as carners of a number of both physiologically and pharmacologically relevant substances [8], serum albumıns constitute a widely studied class of proteins, so that a very extensive literature exists on this topic (e.g, $[5,9,14])$.

Among the substances that are bound to and carried by serum albumins, anti-inflammatory drugs have been extensively studied, and the binding phenomena have been quite well charactenzed $[4,11,16]$, particularly with respect to kinetics (e.g., [7,12]). Nevertheless, using non-steroidal anti-ınflammatory drugs in the course of studies concernıng the serum albumins binding behaviour, we came across some unexpected results, suggesting a dependence of the binding upon the conformation assumed by the protein under different conditions.

The present work reports the results obtained in the course of these studies, covering some aspects of the binding of two of these drugs-indoprofen and indomethacin-to the human serum albumin The aim of this study is actually to investigate the role of the protein in the binding, and, more specifically, the effects of the environment parameters and of the protein concentration itself on the protein conformation and thus on the binding phenomena
METHOD

\section{Detection Methods}

Labelled indoprofen and indomethacin were quantitatively determıned by countıng sample aliquots in a LKB model 1211 scintillation counter (LKB Produkter, Bromma, Sweden) equipped with an external standard accessory Human serum albumın (HSA) was quantified spectrophotometrically, using an extınction coefficient $(01 \%)$ of 053 at $277.5 \mathrm{~nm}$ [11], or by the Lowry assay [6].

Binding was measured either as described under "detection methods" after separation of the incubation mixture by steric exclusion chromatography, or by following the spectral modifications of the protein aromatic chromophores, as described under "ultraviolet spectroscopy "

\section{Chromatography}

Stenc exclusion chromatography was performed with a $7.6 \times 600 \mathrm{~mm}$ TSK G3000SW or $76 \times 300 \mathrm{~mm}$ TSK G2000SW column (Toyo Soda Ltd., Tokyo, Japan) equilibrated with 10 $\mathrm{mM}$ tris- $\mathrm{HCl}$ pH 7.4 plus $10 \%$ ethylene glycol (henceforth called tris buffer) and eluted at $2.2 \mathrm{ml} \times \mathrm{cm}^{2} \times \mathrm{min}^{-1}$ Ethylene glycol was used in the elution buffer to obtain a quantitative recovery of the free drug. Reverse phase chro-

\footnotetext{
'Requests for repnnts should be addressed to L Gıorgı Roda, Dıparımento dı Medıcına Spenmentale. Unıversıtà deglı Studı "Tor Vergata," Via O Raimondo, 100173 Roma, Italy
} 
matography was performed using a $4.6 \times 100 \mathrm{C}$ - 18 column (S10 ODS, Phase Separation Ltd., Queensferry, U K ) The column was eluted at $6 \mathrm{ml} \times \mathrm{cm}^{2} \times \mathrm{min}^{-1}$ with a gradient of $\mathrm{CH}_{3} \mathrm{CN}$ in $25 \mathrm{mM} \mathrm{H}_{3} \mathrm{PO}_{4}$

Reverse phase chromatography performed under isocratic conditions was also used to control the purity of the drugs. Under the test conditions, the labelled indomethacin was found to be approxımately $97 \%$ pure. and the labelled indoprofen $93 \%$ pure

To optımıze the reproducibility of the chromatographic procedures, a "filled loop" injection technıque was employed A $300 \mu$ l loop and a $100 \mu$ l loop were used with a Rheodyne 7125 valve (Rheodyne Inc, Cotatı, CA) for steric exclusion and reverse phase chromatography respectively Three runs were made for each sample, and the results averaged

\section{Ultraviolet Spectroscopy}

Ultraviolet spectra were recorded with a Cary 219 spectrophotometer (Varian Associates, Palo Alto, CA) equipped with a thermostatted cell assembly The spectrophotometer was connected in-line to a Hewlett Packard model $86 \mathrm{~B}$ desk-top computer (Hewlett Packard Co, Palo Alto, CA) via a Varian 954550 module and a HP 82941 A BCD interface

To record difference spectra, Hellma type 238 QS double-sector cells were used (Hellma Gmbh, Mullheım/Baden, DBR) The compartments of both cuvettes were filled with a constriction pipette, the cuvettes were placed in the thermostatted sample compartement and the temperature was allowed to balance off. The base line was zeroed, recorded, and stored in the HP86 penpheral memory. The sample cuvette was mixed and the difference spectrum was recorded in the computer and subsequently analyzed with the appropriate software

Because of the high absorbance levels, difference spectra cannot be recorded with the double-sector cells at very high protein concentration Therefore, these spectra were recorded using 10,05 and 02 optical path cuvettes (Hellma type 201/202). The cuvettes, filled with the appropriate buffer, were placed in the spectrophotometer cell holder and the base line was recorded The sample cuvette was removed, emptied, dried and refilled in turn with pure protein, protein plus ligand and free ligand at the correct concentrations and the relative spectra were recorded. The absorption spectra were stored in the computer and analyzed as described below

\section{Data Reduction}

The spectrophotometnc data stored in the HP 86 magnetic memory were analyzed off-line The concentrationdifference signals were computed by separately recording the absorption spectra obtained at different protein concentrations and by storing them in the magnetic memory of the computer The signals were then weighed using a factor corresponding to the difference in the original concentration multiplied by the reciprocal of the optical path used to record each spectrum The less concentrated solution was obtained diluting the more concentrated one, and the same set of cuvettes was used in all the expenments Using cuvettes of the appropriate pathlength, the recorded absorbances were maintained in the range of $05-15$ Thus, within the spectral range examined, the signal-to-noise ratio of the instrument was better than 5 to $10^{4}$. Therefore, the major source of error was due to pipetting This was minimized using the same set

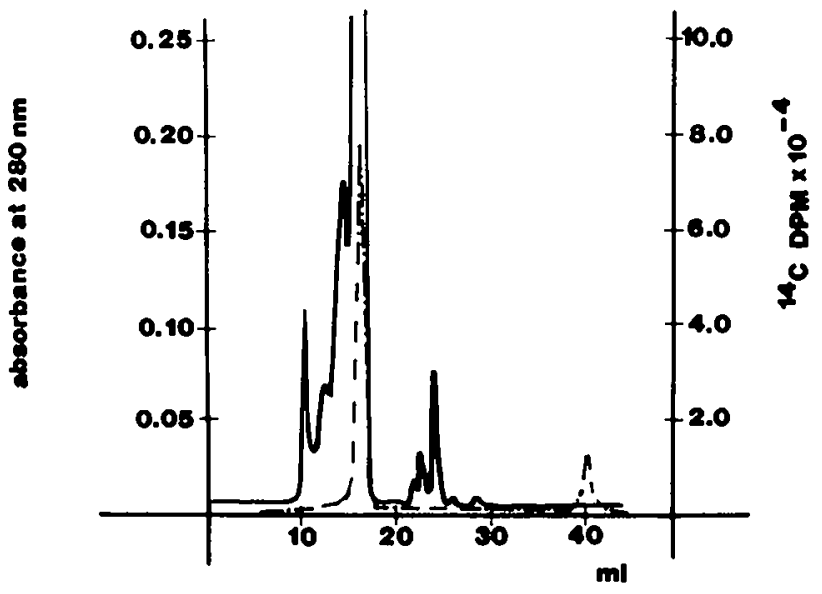

FIG I Steric exclusion chromatography of labelled indomethacin incubated $\left(3\right.$ minutes at $37^{\circ} \mathrm{C}$ ) in whole plasma Incubation and chromatographic conditions as described in the text The solid line represents absorbance at $280 \mathrm{~nm}$, the dash-dotted lıne represents indomethacın DPM

of constriction pipettes The reproduciblity of the pipettes used was checked and found to be approximately $0.5 \%$ of the measured volume So, since two pipettings were necessary, the potential maxımum error was about $1 \%$ of the nomınal concentration.

Difference spectra at high protein concentration were computed from the previously-recorded absorption spectra To take into account volume variations, the correct absorbance was computed as the product of the recorded absorbance multiplied by the original volume and divided by the final volume. Then, the difference spectra were calculated by adding the separately-registered protein and ligand spectra, and by subtracting the result from the pure protein spectrum

\section{Material}

Human blood, freshly collected from healthy volunteers, was centrifuged $(10 \mathrm{~min}$ at $2000 \times \mathrm{g})$ in a refrigerated centrifuge Supernatant plasma-pooled to average the results-were stored under liquid nitrogen until used. Indomethacın, 1-(p-chlorobenzoyl)-5-methoxy-2-methyl-3-ındolacetic acid was purchased from Sigma Chemical Co (St Louis, MO), and ${ }^{14} \mathrm{C}$ indomethacin from the Radiochemical Centre (Amersham, U.K) Indoprofen, 2-[4-(1-carboxyethyl) phenyl-1]isoindolinone, and ${ }^{14} \mathrm{C}$ indoprofen were a gift from Farmitalia Carlo Erba (Milan, Italy). Human serum albumın was obtaıned from Serva Feinbıochemı (Heidelberg, DBR) $\mathrm{CH}_{3} \mathrm{CN}$ for reverse phase chromatography was "Lichrosolv" grade from E Merck (Darmstadt, DBR) All other chemicals used were of a reagent grade and used without further purfication

\section{RESULTS}

\section{Role of the Environmental Parameters}

Indomethacin binding in plasma When whole human plasma was incubated for different periods of time with labelled indomethacin $\left(25 \times 10^{-9}\right.$ moles in $\left.500 \mu l\right)$ and the incu- 


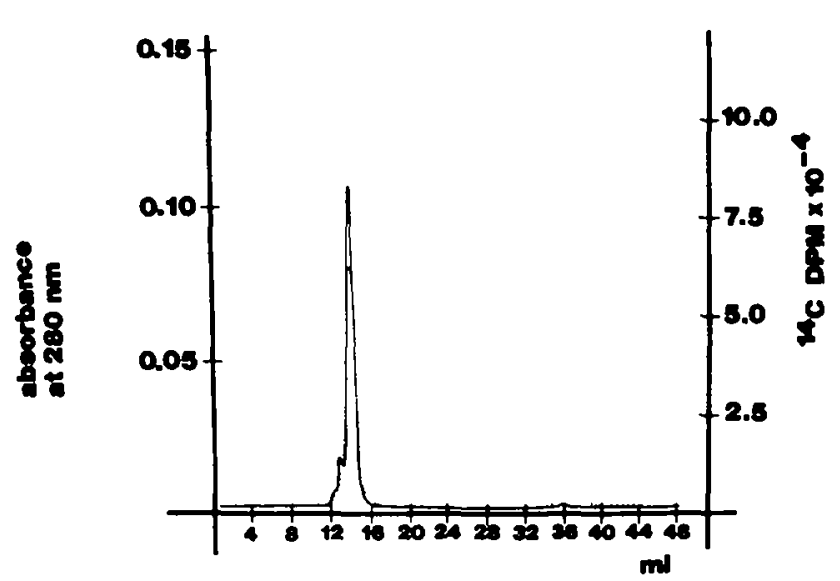

FIG 2. Stenc exclusion chromatography of labelled indomethacin incubated $\left(3\right.$ minutes at $\left.37^{\circ} \mathrm{C}\right)$ in tris buffer. Incubation and chromatographic conditions as described in the text The solid line represents absorbance at $280 \mathrm{~nm}$, the dash-dotted line represents indomethacin DPM

bation mixture was fractioned by steric exclusion chromatography, results such as the ones shown in Fig. 1 were obtained. The solid line in the figure-which refers to a 3 min incubation time-shows the absorbance at $280 \mathrm{~nm}$, while the dash-dotted line indicates ${ }^{14} \mathrm{C} \mathrm{DPM}$. In the figure, the radioactive label is distributed in two peaks. The first one, accounting for $74 \%$ of the total radioactivity, is eluted at a volume corresponding to the elution volume of pure HSA. The second radioactive peak is eluted at the volume of the free indomethacin. The same experiments were repeated at different incubation tımes, obtaining the results described under "tıme dependence" and indicated in Fig. 4

Indoprofen binding in plasma The experiments described in the previous paragraph were repeated using indoprofen-instead of indomethacin-as ligand. Even in this case the major part ( $67 \%$ at 3 minutes) of the radioactive label was found to be associated to the serum albumın.

Indomethacin binding in buffer. Labelled indomethacin $\left(2.5 \times 10^{-9}\right.$ moles in $500 \mu$ l) was incubated with HSA in tris buffer for different periods of time. The concentration of the protein was $50 \mathrm{mg} / \mathrm{ml}$, which is approximately the physiological concentration of this protein in human plasma, and the incubation mixture was fractioned by steric exclusion chromatography as described under the Method section. The results for 3 minutes of incubation are shown in Fig 2. Even in this case, two radioactive peaks were obtained However, only $42 \%$ of the radioactive label (at 3 minutes) is eluted in association with the serum albumin, in contrast with the $74 \%$ bound measured in whole plasma at the same incubation tıme

Indoprofen binding in buffer. The same experiments were repeated under the same conditions with indoprofen as the ligand, and completely different results were obtained In this case, the major part of the radioactive label was eluted at the free drug elution volume, and-at 3 minutes-only $1.7 \%$ of the drug was found to be associated to the serum albumin This result strongly contrasts with the $67 \%$ of albuminassociated drug measured when the incubation was performed in whole plasma with the same substance.

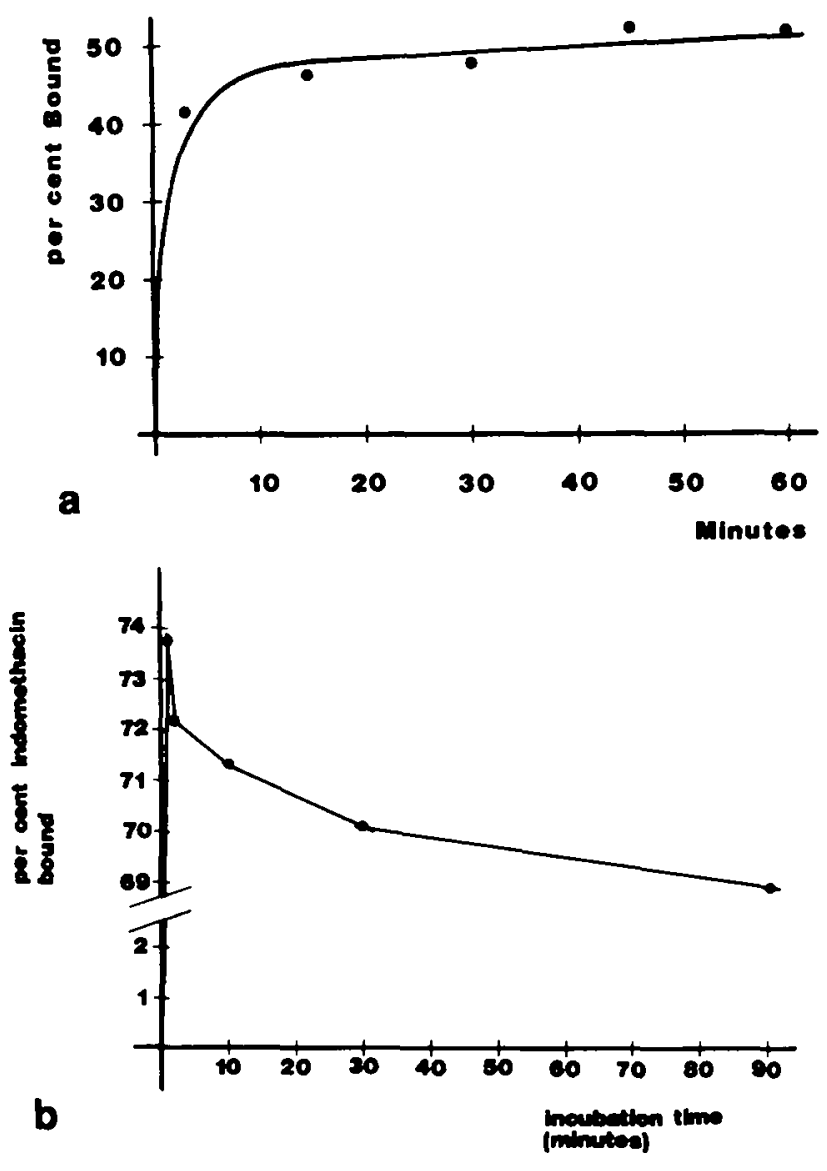

FIG 3 Panel a HSA-bound indomethacin as function of the incubation time Labelled indomethacin was incubated with HSA in tns buffer and the incubation mixture was separated as described in the text The data are expressed as bound drug as percent of the total Solid circles represent experimental points (average of three runs) Panel $b$ represents the same data as panel a, but indomethacin was incubated in whole plasma

\section{Time Dependence}

Indomethacin $\left(25 \times 10^{-9}\right.$ moles $)$ was incubated in the presence of HSA $(50 \mathrm{mg} / \mathrm{ml})$ in tris buffer, or in whole plasma, as described previously. The reaction was allowed to proceed for amounts of tıme varying between 30 seconds and 90 minutes, and the reaction mixtures were separated by steric exclusion chromatography.

When the expenments were performed in buffer, a steady, though modest, increase of the bound indomethacin was evidenced, as predictable, at the longer incubation times (e.g., from 42 to $50 \%$ bound between 3 and 60 minutes, solid line in Fig 3 panel a). Opposite results were obtained when the same experiments were performed in plasma. As shown in Fig. 3, panel b, at the longer incubation times (that is, beyond 3 minutes) a limited decrease of the bound drug became evident in lieu of the increase evidenced in buffer.

The latter result can be interpreted in two ways: either the albumın-bound drug is partıally metabolized in plasma, or else it binds other plasma components with kınetics slower than those of the serum albumin.

To verify the first hypothesıs, labelled indomethacin was incubated for up to 90 minutes with whole plasma, and the 


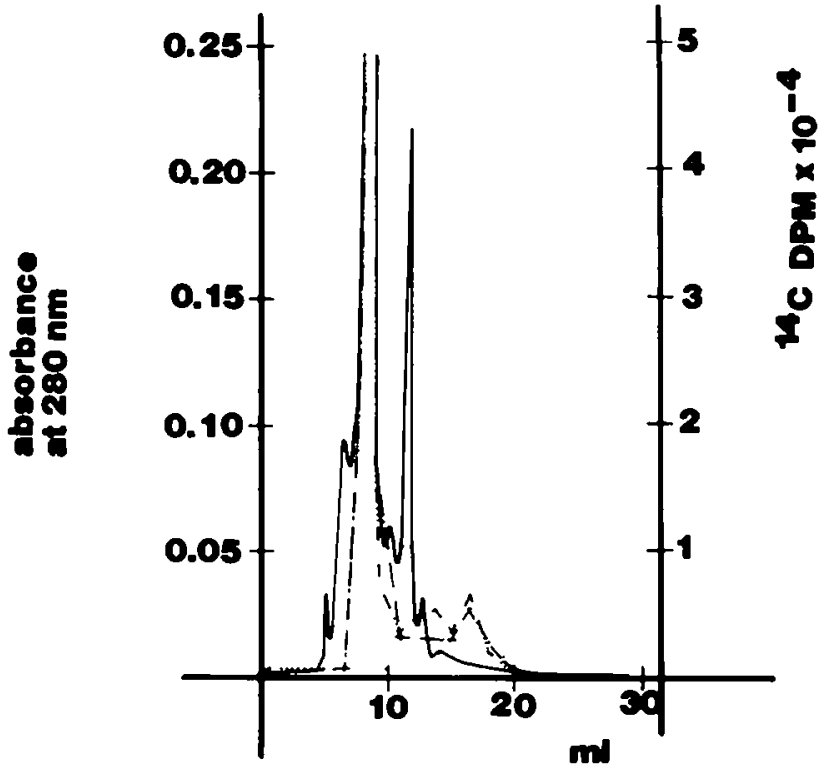

FIG 4 Steric exclusion chromatography of indomethacin incubated in whole plasma Incubation and chromatographic procedures as described in the text The solid line represents absorbance at 280 $\mathrm{nm}$ The dash-dotted line represents indomethacin DPM at 1 mınute of incubation and the dash-three dots line represents indomethacin DPM at 90 minutes of incubation

Incubation mixture was fractioned by reverse phase chromatography as described under the Method section Under these conditions the binding is destroyed by the organic modifier and over $96 \%$ of the label is eluted at the position of the intact indomethacin, thus makıng the hypothesis of drug degradation an unlıkely one

The second hypothesis was investigated as described in the previous paragraph, but the incubation mixture was fractioned on a G2000 column This was done because of the hypothesis that some of the radioactive label may bind low molecular weight plasma components which are not separated from the free drug by the $\mathrm{G} 3000$ column The results of this experiment are shown in Fig 4 The dash-dotted line in the figure indicates the radioactivity after 1 minute of incubation. Two main radioactive peaks are evident, corresponding to the HSA and free drug elution volumes On the other hand, in the chromatogram relative to 90 minutes of incubation (dash-three dots line), three radioactıve peaks are separated The peak eluted at intermediate volume, not present at the short incubation times, very likely represents indomethacin bound with slow kinetics to plasma material of a relatively low molecular weight This interpretation is also confirmed by quantitative measurements. Indeed, the indomethacin eluted at the intermediate volume almost exactly corresponds to the decrease in the albumin-bound drug shown in Fig. 3b

\section{Serum Albumin Concentration}

When binding experiments were performed with indomethacin in aqueous buffer at an HSA concentration of 1 $\mathrm{mg} / \mathrm{ml}$, no bındıng at all was evidenced Therefore, a series of binding experiments were performed at different protein concentrations to ascertain the possible role of this parameter Labelled indomethacin $\left(2.5 \times 10^{-9}\right.$ moles in $\left.500 \mu \mathrm{l}\right)$ was

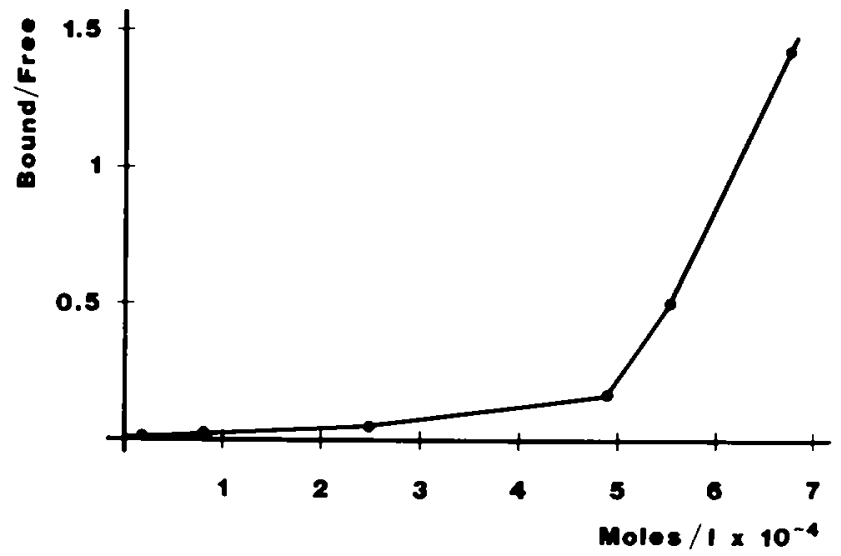

FIG 5 HSA-bound indomethacin as function of the serum albumın concentration Labelled indomethacin was incubated 3 minutes at $37^{\circ} \mathrm{C}$ with the HSA concentrations indicated, and the incubation mixtures were fractioned by stenc exclusion chromatography The results are plotted as bound/free drug against the proteın molar concentration (average of three runs)

Incubated for 15 minutes at $37^{\circ} \mathrm{C}$ in tris buffer in the presence of $\mathrm{HSA}$ at concentrations ranging from 1 to $45 \mathrm{mg} / \mathrm{ml}$ The incubation mixture was separated by steric exclusion chromatography on the G3000 column, and the results plotted as bound/free ligand versus the protein concentration (Fig 5) The curve shown indicates a marked dependency of the bound drug on the albumın concentratıon, and also an abrupt change in the slope of the curve at a concentration correspondıng to approxımately $30 \mathrm{mg} / \mathrm{ml}$, as further described in the next paragraph

\section{Serum Albumin Conformatoon}

As indicated in Fig 5 , the relationship between the protein concentration and the drug bound is linear up to approximately $30 \mathrm{mg} / \mathrm{ml}$ Beyond this concentration, the slope of the curve becomes steeper This phenomenon could be related to a conformational change of the protein molecule, such as to favour the protein-drug interaction If this hypothesis is correct, the protein conformation at high concentration should be different from its conformation at low concentration Moreover, an abrupt conformational change should become evident in the vicinity of the critical concentration of $30 \mathrm{mg} / \mathrm{ml}$

To verify this hypothesis, ultraviolet spectra of human serum albumin were recorded at different proteın concentrations, and the results analyzed as described under the Method section The difference spectra between 55,40 and $20 \mathrm{mg} / \mathrm{ml}$ and $1 \mathrm{mg} / \mathrm{ml} \mathrm{HSA}$ are shown in Fig 6 The signals thus obtained are totally positive, and exhibit two strong maxima, at 279-280 and 286-287 nm plus a series of ripples between 250 and $270 \mathrm{~nm}$. It is also noteworthy that the ratio of the two maxima centered at 2796 and $2893 \mathrm{~nm}$ in the 55 $\mathrm{mg} / \mathrm{ml}$ spectrum changes with the changes in the serum albumın concentration, ranging from 133 to 064 (shorter wavelength divided by longer wavelength)

The concentration difference signals thus calculated seem to be generated by differences in the protein tertiary structure directed towards a polarity reduction of the chromophores' environment when the protein is at low con- 


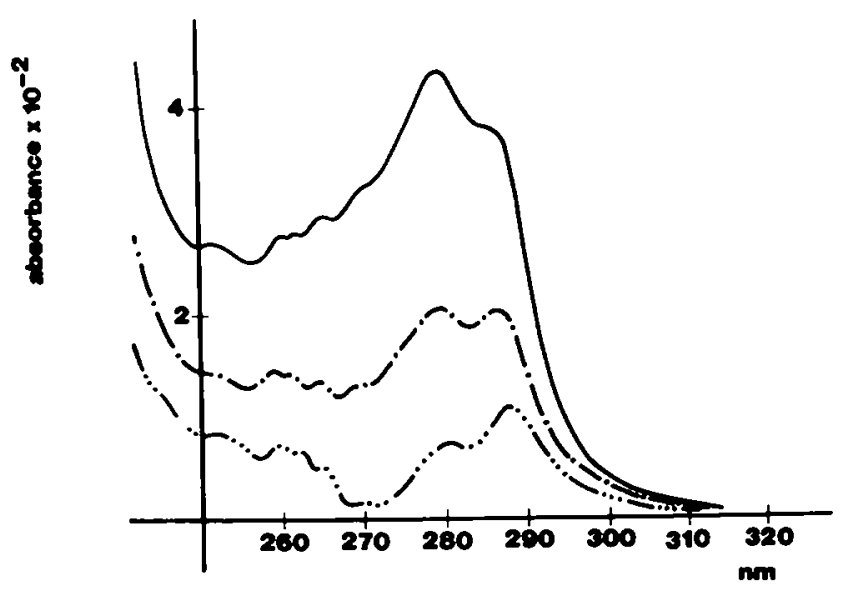

FIG 6 Concentration-difference spectra of HSA in tris buffer calculated against the $1 \mathrm{mg} / \mathrm{ml}$ spectrum The solid line represents the 55 $\mathrm{mg} / \mathrm{ml}$ spectrum, the dash-dotted line represents the $30 \mathrm{mg} / \mathrm{ml} \mathrm{spec}$ trum and the dash-three dots line represents the $20 \mathrm{mg} / \mathrm{ml} \mathrm{spectrum}$

centration. Actually, both the position of the two maxima and the pattern of the concentration-difference spectra correspond very well to an HSA perturbation spectrum This is clear if the curve representing the $1-20 \mathrm{mg} / \mathrm{ml}$ difference spectrum (Fig 6) is compared to Fig. 7, which shows an HSA perturbation spectrum for a transfer from 0 to $10 \%$ ethylene glycol [15] Since the spectrum recorded at the lower protein concentration was subtracted from the spectra recorded at high protein concentration, the resultıng positive differences can be interpreted as generated by a reduction of the environment polarity of the less concentrated protein in respect to the more concentrated one.

Moreover, the environment polarity variation does not follow linearly the change in the protein concentration. Indeed, Fig 8 shows the dependence of the $279 \mathrm{~nm}$ signal upon the HSA concentration. The curves obtained by plotting both bound indomethacin (Fig. 5) and HSA conformational changes (Fig. 8) against the protein concentration follow the same general pattern. This certainly favours the hypothesis that the observed differences in binding are dependent on a conformational change in the protein molecule.

Finally, control experiments were performed to ascertain the possible role of ethylene glycol on the HSA concentration-dependent structural changes Concentration-difference spectra were recorded as described in the previous paragraphs, using as buffer $10 \mathrm{mM}$ tris- $\mathrm{HCl} \mathrm{pH} 74$ with no ethylene glycole Under these conditions (not shown), the detalls of the fine structure of the spectra understandably differed from the ones registered in the presence of the perturbing agent Nevertheless, both the general pattern of the spectra and the differences measured were in good agreement with the ones measured in the presence of ethylene glycol, thus disproving the hypothesis that the described phenomena may be caused by the presence of the glycol

\section{Bınding Under Denaturing Conditıons}

The evidence presented so far tends to favour the hypoth esis that the binding phenomena are controlled by the prefer-

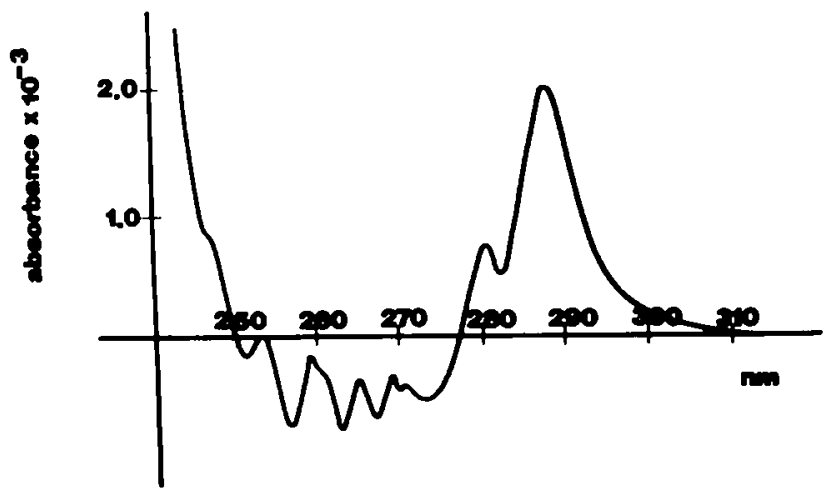

FIG 7 Perturbation spectrum of $2 \mathrm{mg} / \mathrm{ml} \mathrm{HSA}$ for a transfer from $0 \%$ to $10 \%$ ethylene glycol in $10 \mathrm{mM}$ tns- $\mathrm{HCl} \mathrm{pH} 74$

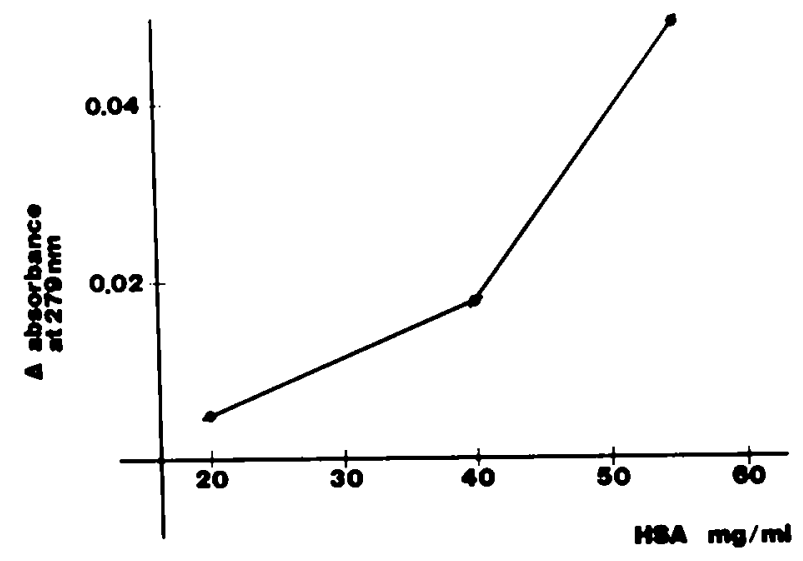

FIG 8 Magnitude of the $279 \mathrm{~nm}$ HSA concentration difference signals as function of the protein concentration Solid circles represent the experimental points

ential exposure of sites (or site) which are at least partially hidden when the serum albumın assumes a lowconcentration conformation, notably in a polar environment To obtain more evidence in this respect, we performed binding experiments under conditions which should lead to a limited and to an almost complete unfolding of the HSA molecule The rationale for these experiments was that - if the hypothesis of a protein's conformational control on the binding were correct-a modest unfolding of the protein could increase, or permit, binding, while a severe unfolding should almost certainly prevent it.

The results of these experiments are summarized in Table 1 Actually, under conditions of a limited relaxation of the protein tertıary structure (4 M guanıdıne- $\mathrm{HCl}$ and unreduced S-S bonds, [10]), a limited binding between HSA and indoprofen can be evidenced. On the other hand, under nondenaturing conditions, this binding can be evidenced only in plasma, but not in aqueous buffer In addition, no bınding at all-either with indoprofen or with indomethacin-can be evidenced with the reduced and carboximethylated protein [4] in $6 \mathrm{M}$ guanidine- $\mathrm{HCl}$, conditions that should maintain the protein in a near-random coll status

\section{DISCUSSION}

The experiments described in the previous section can be summarized as follows 
TABLE 1

PERCENT OF EACH DRUG BOUND TO HSA AT 3 MINUTES OF INCUBATION

\begin{tabular}{|c|c|c|}
\hline & Indomethacın & Indoprofen \\
\hline Whole plasma & 74 & 66 \\
\hline $\begin{array}{l}\text { Natıve proteın in } \\
\text { tris buffer }\end{array}$ & 42 & 2 \\
\hline $\begin{array}{l}\text { In } 4 \mathrm{M} \text { guanidine- } \mathrm{HCl} \\
\text { in } 10 \mathrm{mM} \text { tris } \mathrm{pH} 72\end{array}$ & 28 & 15 \\
\hline $\begin{array}{l}\text { In } 6 \mathrm{M} \text { guanıdıne- } \mathrm{HCl} \\
\text { in } 10 \mathrm{mM} \text { tris pH } 72\end{array}$ & 0 & 0 \\
\hline $\begin{array}{l}\text { Reduced and carboxy- } \\
\text { methylated protein in } \\
6 \mathrm{M} \text { guanıdine-HCl in } \\
10 \mathrm{mM} \text { tris pH } 72\end{array}$ & 0 & 0 \\
\hline $\begin{array}{l}\text { Performic acid-oxıdızed } \\
\text { proteın in } 10 \mathrm{mM} \text { tris } \\
\text { buffer }\end{array}$ & 2 & 3 \\
\hline
\end{tabular}

Protein concentration. $50 \mathrm{mg} / \mathrm{ml}$ except in plasma Tns buffer 10 $\mathrm{mM}$ tns- $\mathrm{HCl}$ pH $72,10 \%$ ethylene glycol

(1) Both drugs, when incubated in whole plasma. are bound to serum albumin (2) Indomethacin-but not indoprofen-binds serum albumin in aqueous buffer while, (3) both drugs bind the HSA under partially-denaturing conditions (4) The binding between HSA and indomethacin is non-linearly dependent on the protein concentration (5) The HSA absorption spectra show concentration-dependent features suggestive of a relatively relaxed structure when the protein is at high concentration Moreover, the spectral modifications are non-linear with the protein concentration, and the departure from linearity parallels the departure from the linearity evidenced for the indomethacin binding

Two of the phenomena evidenced seem to be related and worth discussing. the absence of HSA-indoprofen binding in aqueous buffer, and the absence of HSA-indomethacın binding at low protein concentration

A possible explanation of both phenomena is that the conformation assumed by the serum albumın in plasma is different from the conformation assumed in the more polar environment constituted by the aqueous buffer In addition, the conformation of the protein can be different at low concentration and at high concentration. In both cases, only one conformation can favour, or permit, binding. Some of the evidence shown under the Results section may help to ascertain the reliability of these hypotheses. First, no binding is detectable-even with indomethacin-at low protein concentration We advanced the hypothesis that, if a conformational change of the protein molecule was responsible for the observed differences in binding. then the albumın conformation should be different at high concentration in respect to the conformation assumed at low concentration Moreover, If the two phenomena are related. the concentration-dependent conformational changes should follow the same pattern as the concentration-dependent binding variations Both aspects of this hypothesis were verified concentration-difference spectra (Fig 6 ) show features that can be attributed to concentration-dependent modifications in the protein structure The dependence of both binding (Fig 5) and spectral modifications (Fıg 8) on the protein concentration follows the same pattern Even if the existence of these phenomena cannot be considered a definite proof of a causal relationship, it may be considered a strong argument in favour of it

Moreover, even the data relative to the binding under denaturing conditions seem to favour the same hypothesis As shown, the partial unfolding of the protein molecule caused by the breaking of the hydrogen bonds in $4 \mathrm{M}$ guanıdine could very roughly mime the relatively relaxed conformation assumed by the protein at high concentration. thus favouring or permitting binding

An intriguing point raised by our results is that several of the effects of the binding to serum albumins of the nonsteroidal antı-inflammatory drugs have been detected at protein concentrations where. according to our data, no binding could be detected These effects include protection from thermal denaturation and from enzymatıc cleavage, differences in UV and CD spectra. differences in heatinduced polymerization and so forth $[1,11,12,13]$ It is certainly possible-although not probable-that both the drugs examıned behave in a very anomalous way in respect to the albumin binding It is also possible that some of the effects reported were due to causes other than the direct protein-ligand interactions Whatever the reason, it seems worth further investigation

In summing, the data reported tend to suggest that protein-drug binding is dependent upon the conformational status of the protein, and that it is favoured or permitted by a relatively loose structure of the HSA Incidentally, it should be noted that a non-linear, concentration-dependent behaviour of a serum albumın has been described elsewhere in the case of bovine serum albumın-leu-enkephalın interaction [2] Hypotheses other than the above mentioned ones are certainly possible To gain a better insight to these phenomena, it seems necessary to obtain thermodynamic evidences, by directly measuring the energies involved in the protein-ligand and protein-solvent interactions as well as in the protein-protein interaction causing the structural rearrangements that seem to be of paramount importance for the protein-drug binding

\section{ACKNOWLEDGEMENT}

We would like to thank Professor Bruno Camerıno for the kınd gift of indoprofen and of labelled indoprofen

\section{REFERENCES}

1. Chignell, C F Optical studies of drug-protein complexes, II Interaction of phenylbutazone and its analogues with human serum albumın Mol Pharmacol 5: 244-252, 1969
2 De Marco, V , R Possenu, F Vita, B Rapposellı, M D*Alagnı and L Gıorgıo Roda Enkephalın-bındıng systems in human plasma, II Leu-enkephalın serum albumın interaction Neurochem Re's 10: 1355-1369, 1985 
SERUM ALBUMIN AND ANTI-INFLAMMATORY DRUGS

1037

3 Hirsh, C H W Reduction and S-carboxymethylation of proteins In Methods in Enzymology, vol XI, edited by $\mathrm{C} \mathrm{H}$ W Harsh New York Academic Press, 1967, pp 199-203.

4 Hutmark, D, K O Borg, R Elofsson and L Palmer Interacton between salycilic acid and indomethacin in binding to human serum albumin Act Pharm Sue 12: 259-276, 1975

5 Kragh-Hansen, $U$ Molecular aspects of ligand binding to serum albumin Pharmacol Rev 33: 17-53, 1981.

6 Lowry, O H , N J Rosenbrough, A L Fart and R J Randall Protein measurements with the Foin phenol reagent $J$ Biol Chem 193: 265-275, 1951

7 Mason, $R$ V and E G McQueen Protein binding of indomethacin Binding of indomethacin to human plasma albumin and its displacement from binding by ibuprofen, phenylbutazone and salycilate, in vito Pharmacology 12: 12-19. 1974

8 McMenamy, R H Albumin binding sytes In Albumin Structare. Function and Use's, edited by V $\mathrm{M}$ Rosenoer and M A Oratz Oxford Pergamon Press, 1977, pp 143-158

9 Meyer, C and D E Guttman The binding of drugs by plasma proteins J Pharmacol Sol 57: 895-918, 1968
10 Nozaky, $Y$ and $C$ Tanford Examination of titration behaviour In Methods in Enzymology, vol XI, edited by C H W Harsh New York Academic Press, 1967, pp 715-734

11 Otagin, $\mathbf{M}$ and $\mathrm{J} \mathbf{H}$ Perrin Circular dichroic investigations of the binding of salicylate and related compounds to human serum albumin Bıochem Pharmacol 26: 283-288, 1977

12 Risen, $A$ The measurement of binding constants using circular dichroism binding of phenylbutazone and oxyphenylbutazone Biochem Pharmacol 19: 2075-2081, 1970

13 Rossini, L Hemming der triptıschen Albumınspaltung durch 2 4-dinitro-phenol Hope Seylers Z Physio Chem 333: 1-4, 1963

14 Vallner, J J Binding of drugs by albumin and plasma proteins $J$ Pharmacol Sal 66: 447-465, 1977

15 Wetlaufer, D B Ultraviolet spectra of proteins and amino acids Adv Protein Chem 17: 303-390, 1962

16 Whitlam, J B , M J Crooks, K F Brown and P V Pedersen Binding of non-steroidal antunflammatory agents to proteins I Ibuprofen-serum albumin interaction Btochem Pharmacol 28: 675-678, 1979 